\title{
PROCESSOS DE CRIAÇÃO E PROJEÇÕES IDENTITÁRIAS: \\ MACHADO DE ASSIS E GUIMARÃES ROSA
}

\section{CREATION PROCESSES AND IDENTITY PROJECTIONS MACHADO DE ASSIS E GUIMARÃES ROSA}

\author{
Rubens Alves Pereira*
}

RESUMO: Machado de Assis e Guimarães Rosa são duas personalidades literárias, dois estilos bastante distintos, seja na concepção de linguagem, seja na visão de mundo. Aproxima-os, contudo, o engenho e arte na ativação das forças expressivas do texto, revelando domínio pleno da língua portuguesa e das modalizações da linguagem literária. No desdobramento de tais questões, farei uma apreciação crítica dos contos homônimos "O espelho", de Machado e Rosa, atualizando, com isso, traços recorrentes dos referidos contos no contexto de suas obras.

PALAVRAS-CHAVE: Machado, Guimarães Rosa, estilos, "O espelho".

ABSTRACT: Machado de Assis and Guimarães Rosa are two literary personalities, two sufficiently distinct styles, either in the conception of language, and either in the vision of world. It approaches them, however, the device and art in the activation of the expressive forces of the text, disclosing full domain of the Portuguese language and the modalization of the literary language. In the unfolding of such questions, I will make a critical appreciation of stories homonyms "The mirror", Machado and Rosa's, bringing up to date, with this, recurrent aspects of related stories in the context of its works.

KEY WORDS: Machado, Guimarães Rosa, styles, “The mirror".

\footnotetext{
* UEFS - Universidade Estadual de Feira de Santana - BA. Professor Titular e Doutor em Literatura Brasileira pela PUC do Rio de Janeiro. E-Mail: rubensreap@yahoo.com.br.
} 



\section{PROCESSOS DE CRIAÇÃO E PROJEÇÕES IDENTITÁRIAS: MACHADO DE ASSIS E GUIMARÃES ROSA}

Estamos diante de uma daquelas datas que, por circunstâncias diversas, prezamos atribuir significados especiais - no caso, uma linha do tempo que, nos seus caprichos e mistérios, uniu o bruxo do Cosme Velho ao mago das artes e ofícios do Sertão mineiro. 1908 - uma data especular para Machado de Assis e Guimarães Rosa, cujo reflexo invertido, de nascimento e morte, encontra agora, em 2008, o arco emblemático, posto que simétrico, de 100 anos. Trata-se de duas personalidades literárias de estilos bastante distintos: no fluxo sintático da narrativa, nos fundamentos semânticos da escrita, na estruturação das imagens, na ambientação, na cosmovisão. Aproxima-os, contudo, a ativação máxima das forças expressivas e da ação instauradora dos textos, revelando o pleno domínio da língua portuguesa, das modalizações da linguagem literária, das dobras metanarrativas. Ambos se notabilizam ainda, no universo das letras ocidentais, pela verticalidade do olhar que perscruta a psicologia individual, as relações humanas, os fundamentos da vida social, as matrizes históricas.

Neste trabalho, após algumas cenas teóricas e molduras críticas, faremos considerações sobre os universos literários de Machado de Assis e Guimarães Rosa. Na seqüência, algumas linhas comparativas entre os dois escritores a partir do conto significativamente (também para este contexto 
comparativo) intitulado "O espelho". Com o seu texto, Rosa estabelece um processo de re-leitura do conto homônimo de Machado, numa espécie de escrita suplementar que, ao mesmo tempo, soa como uma homenagem ao genial escritor carioca.

\section{Molduras, Modulações}

Jorge Luis Borges, no prólogo do livro História universal da infâmia, destaca o que poderia ser uma poética da leitura, a qual estaria na base de seu processo criativo. Diz Borges: "Às vezes acredito que os bons leitores são cisnes ainda mais negros e singulares que os bons autores. Ler, além do mais, é uma atividade posterior à de escrever; é mais resignada, mais atenciosa, mais intelectual" (1986, XXVII). Pode-se ver, nesse Borges escritor/leitor, uma perspectiva de disseminação de códigos que subverteria, para o senso comum, a idéia de representação, desnaturalizando a percepção do empírico através do engenho e arte da linguagem. Escrever carrearia, sobretudo, o ato da leitura: dos sinais, dos signos, dos códigos, dos textos, das texturas, das forças e formas do sentido, dos corpos do mundo. Nesse intercurso, que aproximaria leitura e criação, inscrevem-se as inversões e reversões de planos (sonho/vigília; fato/fábula; autor/leitor; concreto/abstrato), atuam as transversalidades no espaço-tempo do homem (passado/futuro; finito/infinito; mortal/imortal) e deflagram-se as flutuações do texto (suas condições de possibilidade). Enfim, o movimento imponderável das leituras ${ }^{1}$ como fundamento da obra - fórmula que orienta, sobretudo, a criação poética do sempre enigmático Borges.

Pode-se dizer, nessa via de reflexão, que toda obra organiza-se, em verdade, na órbita de leituras ou releituras diversas, com seus movimentos circulares em que mundo e linguagem se referendam como campos autônomos mas provisórios e, em certo sentido, interdependentes: convergentes, complementares, antagônicos ou reversíveis. Tais premissas são fundamentais para a aproximação que queremos dos dois escritores cujas pontas de vida e morte se tocam em 1908, Machado e Rosa - a lâmina e a floração da linguagem.

Essa imagem/miragem de uma poética inspirada nas bifurcações borgianas aponta, em boa medida, para questões cruciais dos estudos literários,

\footnotetext{
${ }^{1}$ Tal formulação aproxima-se da idéia peirciana de signo (in: SATAELLA, 1992), cujo interpretante requisita um fluxo infinito de novos signos.
} 
como por exemplo, o lugar da autoria, o princípio da originalidade, a condição do leitor, o primado da realidade, a manufatura dos contextos. Ao leitor crítico não há como ignorar as distâncias, nem como suprimir as pontes teóricas nas suas travessias de leitura; não há como se resguardar impunemente na obra, nem como se respaldar inteiramente no mundo. Escrever é ofício do além, argumentaria um cético, e cínico defunto autor, acreditando que todo sentido só se revela após, para além da morte das convenções e da força normativa das conveniências e aparências. Narrar é muito perigoso - diria um sertanejo encabulado com as forças dialógicas e demoníacas do mundo.

Visto isso, na esperança, talvez, de balizar o percurso que se propõe, vamos ao que aqui já se inicia: um olhar reflexivo sobre as obras de Machado de Assis e Guimarães Rosa, buscando alguns parâmetros lingüísticos e literários de aproximação (confluências, divergências, suplementações, desvios). Se o ano de 1908 é emblemático por espelhar os momentos extremos da existência desses dois autores consagrados da literatura brasileira, os contos intitulados "O espelho" (Machado, em 1882; Guimarães, em 1962, exatamente 80 anos depois), são também concentradores de significados especiais na busca dos possíveis diálogos entre eles, autores que apresentam universos de representação, visão de mundo e interesses estético-filosóficos, em princípio, bastante distintos.

Formulada nessa perspectiva, a presente leitura engloba duas dimensões que ganham plena visibilidade: De um lado, considera-se a obra em sua inarredável condição de linguagem e, do outro, a temos em sua inserção social, em sua inalienável condição de fato historicamente situado, imerso nos processos materiais, ideológicos e imaginários da sociedade.

Pode-se partir de questões básicas inerentes aos fundamentos da obra: Como o escritor Machado de Assis supera a coerção da língua ${ }^{2}$ e se sobrepõe à institucionalização dos discursos para rastrear, constranger ou desnaturalizar as mais emblemáticas formas de ser e de estar no Brasil do século XIX? Ou: como o discurso machadiano solicita referências e referentes diversos, colocando-os em situação discursiva ao mesmo tempo instável e precisa - demolidora de fronteiras retóricas e marcas ideológicas, mas fixadora de tipos psicológicos e quadros sócio-culturais? Noutro contexto: Por que o

\footnotetext{
${ }^{2}$ Contra o aspecto coercitivo da língua, diz Roland Barthes em sua Aula (s/d), a literatura trapaceia com a língua e trapaceia a língua.
} 
regionalismo radical de um Guimarães Rosa, de incontestável valor antropológico, documental e histórico, pode ser concebido como uma "região da arte", na precisa imagem com que Antonio Candido saudou o acontecimento Sagarana em nossa literatura? Ou: Como a sedimentação histórica de uma região, os ermos sem fim do grande sertão, se transfiguram, com Rosa, em aventuras exemplares, em espantosas lutas, em miríades de seres e sentidos, em incessante movência de mundo, os mundos? E, por fim: Que imagens ou miragens se espelham nas (re)escritas e (re)leituras desse escritores-filósofos?

Contemplar tais questões implica, obviamente, perseguir o dinamismo próprio de cada linguagem, de cada código, bem como, a força gravitacional das realidades que as impulsionam e dos contextos que as informam. Trata-se, em princípio, de uma espécie de sedução crítica pelos traços singulares das artes e ofícios da ficção, nos seus caminhos que se cruzam ou se bifurcam, nas suas forças de atração, nas suas zonas de atrito.

"Em qualquer área de estudo ainda não reduzida (ou elevada) ao status de uma ciência genuína, o pensamento permanece cativo da forma de linguagem com que se define", diz o historiador americano Hayden White" (apud Luis Fernando Veríssimo, in "Ironic mode", Salvador: Jornal A Tarde, 14/10/2007, p. 26), tendo em vista, sobretudo, o estilo dos filósofos da história (para ele Hegel, Marx, Nietzsche e Benedeto Croce). Esse princípio, creio, estender-se-ia às regiões da arte e, em certa medida, aos estudos literários e culturais. Nessa idéia de que "o pensamento permanece cativo da forma de linguagem com que se define", me interessa menos o que pode haver de relativismo de fundo, abalando verdades ou veredictos históricas e conceituais, do que a instigante constatação das potencialidades inerentes à linguagem. Esse princípio de White repõe a questão da dimensão do real nas malhas do texto, ou, de outra forma, dos limites do texto como inevitável recorte no dinamismo da realidade. Daí a necessidade do paradoxo, da ironia, das figuras - formas singulares de pensamento, estruturas de linguagem aparelhadas mais para apreender forças do que para representar fatos. O pensamento, assim, nas malhas dos significantes, menos que sob o jugo do nonsense relativista, traria inscrições outras, de base analógica, como suplemento à lógica segmentada do racionalismo.

Nessa aproximação dos universos de Machado e Rosa, um dos elementos privilegiados será a carga performática e expressiva dos seus discursos 
literários, na contraface de suas reflexões filosóficas de ampla repercussão psicológica e sócio-cultural. Nesse movimento, sobressaem aspectos variados da polêmica questão da identidade, seja como lugar de reconhecimento de imagens próprias, pessoais, seja como substrato de práticas sócio-culturais, ou ainda, como planos balizadores da linguagem, da própria literatura. Pela questão da identidade, assim concebida, passam os seres e o próprio ser da linguagem. Passam as faces espelhadas dos eleitos escritores.

As perguntas em torno do regional e do nacional, ao longo da história literária brasileira, adquiriram colorações ideológicas e assumiram estratégias críticas e discursivas diversas. Tais incursões por essas verdadeiras molas-mestras da formação cultural brasileira já não se apresentam na ordem do dia da nossa historiografia literária. As polêmicas e a tensão crítica em torno do nacional e do regional (com vistas no universal), foram arrefecendo-se, na proporção mesma em que as forças de representação identitária se deslocaram ou se expandiram em novas direções, abarcando demandas políticas emergentes e grupos sociais específicos. Doravante, nos deparamos com conceitos mais plásticos de identidade. No dizer de Boaventura de Sousa Santos (1996), operamos mais com processos de identificação em curso do que com traços fixos e pretensamente definidos de identidade. Trata-se, em termos atuais, de espaços de negociação, com identidades múltiplas, formas híbridas, diaspóricas, mestiças.

A questão da identidade, hoje, desloca-se do lugar das determinações essenciais para o espaço das articulações estratégicas. A Identidade abre-se, portanto, ao corpo mutante das diferenças étnico-culturais e ao jogo móvel das representações discursivas. Cada vez mais, sobre a noção de identidade agem processos distintos, ora de tendências fundamentalistas, ora agenciados por demandas políticas - estratégicas ou contextuais. Compreendendo, com Charles Sanders Peirce (in: SANTAELLA, 1992), que o mundo está em expansão porque os signos estão em expansão, diria que a noção de identidade no mundo contemporâneo desloca-se em torno de uma semiose complexa que desestabiliza noções tradicionais e estáveis. A identidade seria, nessa perspectiva semiótica, um sistema aberto e volátil, em permanente (de)codificação. As identidades, com suas determinações mais ou menos precisas, definem-se também por suas transversalidades. 


\section{Machado de Assis: as demandas e as fraturas do texto}

Machado de Assis (1839-1908) é escritor autodidata que se tornou "a nossa

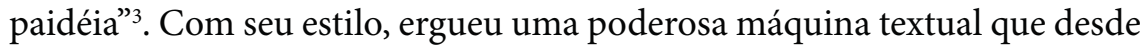
o século XIX não pára de produzir sentidos, de revolver valores, de orientar olhares, de alimentar a língua. O projeto literário machadiano inserese no ainda provinciano e preconceituoso ambiente cultural brasileiro da época como um desconcertante espaço arejado da consciência artística e do pensamento crítico nacionais. Uma luz cuja intensidade encantava, ao tempo em que incandescia leitores e críticos. E a história da crítica brasileira mostrou que a obra de Machado de Assis exigiu um longo e apurado processo de aprendizado de leitura, fato que ganha plena visibilidade na compreensão da obra Dom Casmurro: Por mais de 60 anos, o Bacharel em Direito Bentinho impôs seu discurso insidioso como uma verdade cristalina, encobriu suas inconfessáveis razões ou motivações com a naturalidade de um discurso engenhoso, solenemente empenhado em confundir seus leitores, num jogo tão sutil como complexo de manipular clichês retóricos e emocionais do senso comum (a pureza da falsa modéstia, o sublime do gosto romântico), de agenciar convenções sócio-culturais legitimadas por uma pseudo-lei do bom senso ${ }^{4}$ (suas prerrogativas aristocráticas de Doutor).

O afinado concerto retórico de Dom Casmurro, com sua linguagem polida e comedida, aparece como a contraface do também desconcertante jogo retórico das Memórias póstumas de Brás Cubas, cuja força motriz do texto é a provocação do leitor, através da con-fusão de princípios, da proliferação de padrões e de uma destemida consciência assumidamente problemática do defunto autor. Ambos, contudo, exemplos marcantes do enigmático e sedutor estilo que predomina na obra machadiana, em especial, a partir da década de 80.

$\mathrm{O}$ ato de narrar pressupõe um movimento de abertura bifronte: para o mundo e para a própria linguagem que (se)narra. Trata-se de um trânsito, um agenciamento de forças formais, de contextos literários e de virtualidades históricas. Tais postulados nos ajudam no aprendizado de obras como a de Machado de Assis, a melhor interagir com seus textos, marcados que são

\footnotetext{
${ }^{3}$ Expressão de Antonio Callado, em depoimento numa "Mesa Redonda" organizada por Alfredo Bosi. In: BOSI, 1982, p. 323.

4 Tomamos aqui os conceitos deleuzianos de bom senso e de senso comum, quando contrapostos às novas forças desencadeadas pelo paradoxo: Bom senso, como sentido único, e do senso comum, como designação de identidades fixas. In: DELEUZE, 1974, p. 3.
} 
pela ironia crítica, pelo humor cético, pelos influxos artísticos e conceituais da modernidade. Visto isso, podemos identificar pelo menos dois grandes movimentos críticos que se estabeleceram em torno da obra de Machado, aqui vistos apenas nas suas formas extremadas, didaticamente dicotomizadas: um, que busca aproximações diretas texto-contexto, traços da segmentação realista, seja de âmbito particular, biográfico, seja no campo cultural, político e ideológico; e outro, que enfrenta mais claramente as articulações metaficcionais e os agenciamentos discursivos que acionam valores históricos (psicossociais, sociopolíticos, ideológicos etc.), e sistemas complexos de conotação, de articulação literária. Vejamos, num único exemplo (por nós já utilizado em outro texto - Pereira, 1999), um processo que, por uma reversibilidade de leitura, presentifica os dois movimentos:

$\mathrm{Na}$ introdução do livro de estética de Ernst Fischer, A necessidade da arte (1983), o escritor Antonio Callado mostra-se ressentido para com Machado de Assis e inconformado com a maneira como ele trata da abolição da escravatura no romance Memorial de Aires:

Quando a gente se lembra de que o criador do Aires era Machado de Assis, um mulato, sua maneira de apresentar a Abolição dá uma idéia de esquizofrenia. É a 'alienação' do artista chegando às raias da alienação mental (FISCHER, 1983, p. 8).

Essa introdução faz parte da primeira edição brasileira (1966) do livro de Fischer. É bastante irônico observarmos que no pórtico de um livro que se propõe a refletir sobre "a necessidade da arte" desponte tão imprevidentemente uma sectária opinião que prima por negar justamente a liberdade e a especificidade da elaboração artística em favor de um discurso engajado, da razão pragmática própria ao discurso político ou ao panfleto.

Após a intempestiva investida de Callado em favor de um discurso literário empenhado aos moldes de um realismo mimético, de um compromisso horizontal com a história, torna-se, no mínimo, curiosa e provocativa a idéia com a qual Ernst Fischer abre o seu livro: "A poesia é indispensável. Se eu ao menos soubesse para quê... Com este encantador e paradoxal epigrama, Jean Cocteau resumiu ao mesmo tempo a necessidade da arte e o seu discutível papel no atual mundo burguês" (Idem, p. 11).

Passado algum tempo, o próprio Callado penitencia-se da açodada crítica feita a Machado. O reparo de Antonio Callado veio em 1980, numa 
mesa-redonda sobre Machado de Assis que foi publicada posteriormente na "antologia e estudos" sobre este autor, em 1982. Nessa mesa-redonda, Mário Curvelo faz referência à citada introdução de Callado ao livro de Ernst Fischer e, em resposta, o autor de Quarup assim se retrata daquela embriagada crítica:

[...] meu respeito por Machado de Assis só tem feito crescer através dos tempos. E, as poucas coisas que imaginava como, digamos assim, restrições que eu poderia fazer, o que me parecia aquela coisa pouco participante, um homem que fugiu, de uma certa forma, às lutas de seu tempo, bobagem! Tudo isso era bobagem minha. O reflexo da história do Brasil na obra de Machado de Assis é absolutamente intoxicante. Quando a pessoa realmente absorve Machado, as lutas do tempo, da República, da abolição... Enfim tudo o que estava acontecendo no tempo dele tem um significado tão forte que é, culturalmente, eu diria, uma coisa tônica (CALLADO, in: BOSI, 1982, p. 323).

E Callado não para por aí, prossegue em sua reverência ao colega escritor, declarando que quanto mais convive com Machado, mais se rende "à presença de um gênio que nos educa. É a nossa paideia, tal como Werner Jaeger tomou a Grécia para explicar os fundamentos da cultura ocidental" (Idem, p. 323).

Segundo Wolfgang Iser, é na "decomposição dos campos de referência do texto", na "seletividade do texto face a seus sistemas contextuais" (1983, p. 390), que podemos flagrar a intencionalidade autoral. Tal operação é indispensável a um olhar crítico que busque a verticalidade do texto machadiano.

Ironicamente, na aproximação dessas duas maneiras de ler Machado de Assis evidencia-se mais claramente o "estilo" do autor, pois os procedimentos textuais passíveis de uma crítica que lhe imputa alienação política ou redutores determinismos biográficos, são os mesmos que permitem extrair as mais agudas e reveladoras percepções críticas: seja dos discursos ideológicos que atravessam as cenas sociais, seja da economia simbólica ou psicológica que matizam os agentes individuais. Como bem assinala Roberto Schwarz, tudo o que Machado diz, "é mediado por uma forma, e só pode ser interpretado através de mediação da forma” (in BOSI, 1982, p. 339). Para além dos conceitos, dos discursos assertivos e autorizados, a própria história factual é obrigada a fazer uma travessia estética, através de pro- 
cedimentos suplementares inerentes à escrita literária: referências transversais, marcações ambivalentes, deslocamentos metanarrativos.

Por ser basicamente nas estratégias textuais que subjaz a maior vitalidade do universo ficcional de Machado (a ação esvazia-se em favor de uma elocução problemática e interativa), talvez por isso, por não ter atentado para este dado, Antonio Callado tenha cometido a infelicidade crítica em relação ao autor de Memorial de Aires. Callado não percebeu num primeiro momento que, ao invés de "alienado", Machado se revela um profundo e consciente crítico daquele grande espetáculo institucional que foi a dita "libertação dos escravos". O escritor percorre os elementos retóricos e os movimentos canônicos subjacentes aos discursos sociais, desmascarando valores ideológicos de uma burguesia ensimesmada, bem como as complexas motivações interiores das personagens.

O paradoxo. A confusão de parâmetros. A sobreposição de planos. Eis algumas frases que poderiam estar na base de uma caracterização do conto "O espelho (Esboço de uma Nova Teoria da Alma Humana)", de Machado de Assis. Trata-se de um texto curto, mas rico em imagens conceituais e em recursos formais que muito dizem do jeito próprio de ser da obra machadiana.

O conto de Machado de Assis ("O espelho") nos coloca ante o paradoxal fenômeno de constituição de uma "alma exterior", que pode ser ampla e absorvente ao ponto de anular a outra alma, a interior. Machado, apesar de identificar as duas almas, fixa-se apenas na que se alimenta nos influxos externos, promovendo um deslocamento de foco que projeta a imagem/ miragem do indivíduo num contexto de máscaras sociais. Da experiência subjetiva mais radical, a que pressupõe uma identidade pessoal (a alma do indivíduo), encontra no olhar demolidor de Machado uma contraparte ideológica que está na base dos valores sócio-culturais. $\mathrm{O}$ individual passa pelo crivo do social, e vice-versa. Assim sendo, a individualidade torna-se paradoxal, posto que desprovida de eixo próprio, e as identidades tendem a ser meramente funcionais, visto que se confinam no teatro das relações e das posições sociais. "O alferes eliminou o homem”, admite a própria vítima (ASSIS, 1994, p. 348).

A ironia machadiana apresenta-se, nesse conto, com grande pujança crítica e filosófica, revolvendo campos diversos, que dizem respeito à constituição das subjetividades, às projeções psicológicas, às coerções sociais, aos labirintos do corpo, às forças do desejo, aos padrões morais, éticos, culturais. 
O conto explora de forma exemplar uma das características marcantes de autor de Brás Cubas, qual seja: a capacidade de agenciar, para o corpo móvel da linguagem, planos e valores diversos. Sobressai, ainda, a linguagem clássica por trás da ironia moderna e do pensamento cético. No mais, em movimento retórico tão discreto quanto preciso, Machado vai desfiando marcas históricas, como a escravidão e suas fraturas; a prestigiada função de alferes, indicando uma sociedade acanhada, com poucas oportunidades de trabalho; a sofisticação retórica do narrador, o qual ocupa um lugar aristocrático na trama e na sociedade brasileira da época.

No espelho furtacor da sua escrita, Machado de Assis passa em revista os vícios e enganos de seu tempo: parodia jogos retóricos e clichês da opinião pública; reencena patéticas coreografias da classe dominante; subverte a ótica de uma impostada elite intelectual. Ante seu texto-espelho, o rei fica nu.

\section{Guimarães Rosa: Sertão Sertões, entre corpo e linguagem}

João Guimarães Rosa (1908-1967) causou grande impacto nos meios literários desde a sua estréia em livro, com a coletânea de contos Sagarana (1946), tendo se consagrado com o portentoso romance Grande Sertão: Veredas, em 1956, ano também da publicação de Corpo de baile, conjunto de novelas que depois seriam distribuídas em dois volumes. Ainda em vida, o escritor mineiro publicaria mais dois livros de contos: Primeiras estórias (1962) e Tutaméia (1967). Outros livros seriam publicados após a sua morte. São títulos que se abrem a um particularíssimo universo sertanejo consubstanciado nos torneios criativos da linguagem: na magia expressiva do vocábulo, na energia contrastiva da sintaxe, no ritmo evocativo das imagens.

Para além de uma meticulosa elaboração textual, Guimarães Rosa acompanhava de perto o processo de ilustração das capas ${ }^{5}$ e de outros espaços convencionais do livro, como as orelhas, a folha de rosto, o índice e a quarta capa. Tais ilustrações, encomendadas e acompanhadas pelo próprio escritor, travam um significativo diálogo com o processo expressivo do livro. Texto e imagem se articulam em níveis diversos. Assim, compõe a obra de

\footnotetext{
${ }^{5}$ Os livros definem-se, como bem observa Alberto Manguel (1997), por uma "corrente de palavras que os encerra, a qual flui do início até o fim, da capa até a quarta capa, no tempo que concedemos à leitura desses livros".
} 
Guimarães Rosa um conjunto de marcas textuais, símbolos, sinais gráficos e desenhos que reafirmam as percepções do mundo e do livro como planos desdobráveis na linguagem, numa dinâmica de recorrências e transposições de elementos formais, conceituais e expressivos.

Em Grande sertão: veredas, por exemplo, ergue-se um mundo em ebulição, com incontáveis interfaces movendo os seres, as coisas e o próprio texto:

- Nonada. Tiros que o senhor ouviu foram de briga de homem não, Deus esteja. Alvejei mira em árvore, no quintal, no baixo do córrego. Por meu acerto. Todo dia isso faço, gosto; desde mal em minha mocidade. Daí, vieram me chamar. Causa dum bezerro: um bezerro branco, erroso, os olhos de nem ser - se viu -; e com máscara de cachorro (...). O senhor ri certas risadas... (ROSA, 1967, p. 9).

A aventura expressiva de Guimarães Rosa é marcada por uma percepção incomum dos fenômenos e amparada numa concepção de linguagem que o habilita a nomear o mundo em suas reentrâncias, a registrar as vibrações mínimas que definem e distinguem as coisas, os seres - suas ações, seus enigmas ${ }^{6}$. Quando perguntado sobre as dificuldades de leitura das suas obras, Guimarães Rosa usava um argumento que, se o afastava de um possível virtuosismo técnico da escrita, projetava-o numa espécie de visão vitalista do mundo, num consórcio íntimo com o quem das coisas, com as virtualidades do real: "Eu não escrevo difícil", disse Rosa, "eu sei o nome das coisas". Saber o nome das coisas parece ser, para ele, falar de dentro, das reentrâncias da linguagem, e por dentro das virtualidades do mundo, buscando o que constitui o acontecimento de cada coisa por ele acionada.

"Quando se vem vindo sertão a dentro, a gente pensa que não vai encontrar coisa alguma", observa o narrador da novela "Buriti", como a advertir para os assombros do vazio aparente nos ermos daquele mundo. O que aqui se entrevê, ganha forma na reflexão de Riobaldo: "Mas o sertão está movimentante todo-tempo - salvo que o senhor não vê; é que nem braços de balança, para enormes efeitos de leves pesos..." (Idem, p. 391). O escritor mineiro, podemos dizer, extrai do acontecimento-sertão as forças moventes de um mundo primevo, das origens, mas que é um mundo dinâmico e

\footnotetext{
${ }^{6}$ Sobre os enigmas na obra de Guimarães Rosa, cf. Pereira, 2001.
} 
atual, ao mesmo tempo múltiplo e singular, presença virtual e corpo vital - o homem, a civilização, a terra e os confins de tudo isso. "A gente só sabe bem aquilo que não entende" (Idem, p. 286).

Para captar as sutilezas do mundo, Guimarães Rosa persegue a utopia de uma linguagem em estado seminal. Cada gesto verbal parece ir relatando um mundo para o qual, até então, não havia figura ou forma definida em linguagem: "- O senhor solte em minha frente uma idéia ligeira, e eu rastreio essa por fundo de todos os matos, amém!", diz Riobaldo. “Sertão: estes seus vazios". (Idem, p. 15 e 27).

Para apossar-se do texto de Guimarães Rosa, é preciso decifrar (que é um comungar, um pendor lírico), a radical manifestação poética que consubstancia as infinitas linhas narrativas. Apropriando-me de uma bela metáfora descritiva de Octavio Paz, diria que Guimarães Rosa "procura na realidade esse ponto de inserção da poesia que é também um ponto de intersecção, centro fixo e vibrante onde se anulam e renascem sem trégua as contradições. Coração-manancial” (1982, p. 309-10). Fraturar o mundo, abrir frinchas com a linguagem e fazer emergir um mundo em linguagem, faturas verbais - eis o ponto de inserção e de intersecção da poética rosiana - "Coração-manancial".

Guimarães Rosa opera um amplo regime de imagens e leituras do mundo que incidem sobre os planos do visível, conjurando as forças invisíveis. À margem das cronologias do real com seus territórios demarcados, Guimarães Rosa propõe e dispõe em sua obra percepções diferenciais, olhares reflexivos, pontos de conversão e inesperadas solicitações perceptivas e conceituais - terceira margem, sertão sertões. "Digo: o real não está na saída nem na chegada: ele se dispõe para a gente é no meio da travessia" (ROSA, 1967, p. 52). Pode-se dizer que, para esse autor dos vastos territórios da arte, nem tudo é sertão, mas há sertão por toda parte. Nem tudo é humano, mas há humanidade por toda parte.

Entrechoque de ficção e realidade, de narrativa e poesia, de lutas e alucinações, o Sertão de Rosa é, simultaneamente, o acontecer de um Brasil arcaico e um florescer de signos, percepções, linguagens. Nos mapas de suas obras, Guimarães Rosa propõe sempre imprevistas travessias. Em suas coisas do mundo-Sertão, encontra-se profundo investimento existencial, sentimento místico, conflitos sociais e densidade histórica. E, sobretudo, amor e zelo extremados pelas linguagens dos 
homens e pelas mensagens do mundo. “Triste é não ter um verso maior que os literários"7.

"O senhor ri certas risadas..." Com essa observação, em meio a variadas incursões narrativas e reflexivas, o problemático narrador de Grande Sertão: Veredas, Riobaldo Tatarana, tanto assinala o desconcerto, como uma certa incredulidade do seu letrado interlocutor. Do narrador a seu(s) ouvinte(s), do texto a suas performances, do mundo a seus teatros, tudo se contamina, e em parte se in-determina pela fina ironia de uma narrativa cuja ambigüidade já se anuncia na imprevista observação de Riobaldo: "O senhor ri certas risadas..." Espraiando-se nas reticências, a frase modulase em várias direções, configurando-se ao mesmo tempo despretensiosa, reflexiva, cúmplice, repreensiva e, ao cabo, metacrítica: A frase aparece no meio do primeiro parágrafo do romance, portanto, a meio caminho entre a explosão cosmográfica do “- Nonada”, que abre as veredas deste formidável livro, e a implacável constatação de que "o sertão está em toda parte", que engloba a condição humana.

Nesse tópico, pode-se dizer que Guimarães Rosa, na verve e na voz de Riobaldo, traz para o corpo do relato, como parte das estratégias narrativas, a dimensão do ouvinte-leitor, não para referendar um tipo de recepção condicionada pela tradição literária brasileira, mas sobretudo para deslocar, na leitura, uma visão de mundo sedimentada. Dessa leitura, que se apresenta no romance como um dos princípios da construção ficcional, à leitura como recepção crítica de um leitor real, veremos que não há muita distância modal, principalmente se considerarmos a diversificada fortuna crítica do autor, ou mesmo o caso exemplar e quase anedótico narrado pelo crítico peruano Emir Rodríguez Monegal. Conta ele que depois de uma longa e ansiosa busca, tem nas mãos o monumental Grande sertão: veredas: "Li e reli tornei a reler as três ou quatro primeiras páginas do romance. Não direi que não entendi nada porque seria exagerar". Em seguida, confessa esse crítico da literatura hispano-americana que o seu considerável conhecimento da língua portuguesa, que lhe permitia "circular sem lágrimas pela literatura brasileira ou portuguesa, parecia nada, frente a essas primeiras formidáveis páginas" (MONEGAL, 1991, p. 52).

\footnotetext{
${ }^{7}$ Verso de Carlos Drummond de Andrade.

8 Tributária do "bom senso" e do "senso comum", no sentido deleuziano, conforme visto antes.
} 
Verificam-se, na alquimia verbal de Guimarães Rosa, processos que tensionam as marcas identitárias dos seres e as coordenadas materiais do mundo. Temos aqui uma das mais impressionantes faces do escritor mineiro, ou seja, a sua capacidade de captar/encenar as forças ativas e reativas dos acontecimentos. Guimarães Rosa prima por uma maneira muito original de flagrar a vida nos seus quase sempre imperceptíveis movimentos (corporais, cósmicos, históricos, mitopoéticos), nos seus enredos sagrados secretos (recados diversos, mensagens cifradas, intangíveis travessias) ou, nas suas conversões de recursos (a ação da providência, força que inesperada brota). Sertão, jagunço, criança, louco, burrinho, boi, onça, árvore, poesia, amor, enredo, estória, passarinho ou outra coisa qualquer, num relance, se projeta no fulcro da matéria vertente da língua e da vida. Neste sentido, Guimarães Rosa não molda, antes modula o seu universo, pois, como define Gilbert Simondon, "moldar é modular de maneira definitiva; modular é moldar de maneira contínua e perpetuamente variável”. (SIMONDON, apud DELEUZE, 1991, p. 36).

O particularíssimo jogo de posições, determinado por instâncias como narração e focalização, cria um espaço intersubjetivo em que elementos diversos intercambiam forças e traços singulares. Para ilustrar esse fluxo contínuo das forças diferenciais emergentes, podemos destacar o conto "Meu tio o Iauaretê", do livro póstumo Estas estórias (1969). O conto nos põe em presença "antenasal" de um onceiro, num lugar ermo dos gerais, que recebe em sua morada um inesperado e, quiçá, perdido viajante. Em forma de monólogo-diálogo desfiado pelo onceiro, onde tempo do enunciado e tempo da enunciação coincidem rigorosamente, o escritor constrói um dramático embate discursivo entre a personagem que se expressa e, através da sua fala, modula o diálogo sem que a voz do seu interlocutor apareça explicitamente na narrativa. Embora apenas o onceiro fale nesse "diálogo", a focalização narrativa engendra um fluxo textual espesso e reflexivo, em que a figura do onceiro passa pelo crivo do olhar do visitante que, por sua vez, é constituído inteiramente na fala daquele. Identidade e alteridade são aqui modulações indissoluvelmente comprometidas entre si, como diferenças que se sustêm apenas na diferenciação, no deslocamento de vozes e visões em direção a paisagens diversificadas da vida. Raramente a linguagem adquire tamanha espessura sem se desprender das teias empíricas e atávicas da vida.

Todo esse jogo de dados textuais, alimentado por percepções e sensações que desafiam os limites do concebidamente humano, chega ao extremo do 
mobilismo quando, diante do viajante e dos ouvintes-leitores, o onceiro se metamorfoseia em onça, superpondo uma organização animal, com sua estratégia existencial felina, a uma organização textual, com sua estratégia narrativa fluida e conceitual.

Nesse processo de dobras e recortes do Iauaretê, em que o mesmo e o outro, homem e fera, voz e silêncio se interceptam no corpo-linguagem da escrita, vemos aquilo que Gilles Deleuze, na sua filosofia vitalista, considera como sendo um mecanismo de "relações transversais" que nos faz falar "do fundo daquilo que não somos”. Diz o filósofo:

o problema não é ser isto ou aquilo no homem, mas antes o de um devir universal animal: não tomar-se por um animal, mas desfazer a organização humana do corpo, atravessar tal ou qual zona de intensidade do corpo, cada um descobrindo as suas próprias zonas, e os grupos, as populações, as espécies que o habitam. (DELEUZE, 1992, p. 15 e 21).

Um grande Sertão (mundo ao mesmo tempo dado e criado) perpassa essa zona de intensidade do corpo poético de Guimarães Rosa, possibilitando-lhe erguer em voz e gesto, em linguagem e silêncio, uma diversidade de seres, de grupos, de espécies, de regimes, de planos; trazendo à fala até mesmo o que não tem palavra, o que se move na infinitude, no horizonte de possíveis que habitam as suas fauna e flora literárias. Aqui podemos entender porque, a exemplo de outros escritores contemporâneos, Guimarães Rosa considera que "a personalidade do escritor, ao escrever, é sempre seu maior obstáculo”. (ROSA, 1991, p. 89).

Avoluma-se na obra de Guimarães Rosa uma dinâmica de configuração de tempos e espaços diversos, que facultam, na disposição textual de seres e enredos, variados processos de mutações, homologias, simulacros, conversões, duplicações, dobras, virtualidades, espelhamentos. Nesse regime, um momento exemplar do escritor pode ser visto no conto "O espelho", de Primeiras estórias (1962). "Quando nada acontece, há um milagre que não estamos vendo", diz o narrador logo ao final do primeiro parágrafo, colocando em xeque todo um regime de fenômenos centrado no visível, nas relações empíricas de causa e efeito. O narrador nos conta "não uma aventura, mas experiência" levada a cabo por raciocínios e intuições incomuns acerca da própria imagem e da identidade como forças mutantes, combinações de diversos vetores, agenciamentos múltiplos. Alertando tratar-se de "fenôme- 
nos sutis", o narrador reflete sobre o "elemento animal" que se inscreve na fisionomia de cada homem, e experimenta a desmaterialização progressiva, até o total desaparecimento da sua imagem ante o espelho. Em decorrência desse processo radical de desarticulação dos próprios referenciais físicos, o narrador chega às questões cruciais daquela narrativa: “[...] despojara-me, ao termo, até à total desfigura. $\mathrm{E}$ a terrível conclusão: não haveria em mim uma existência central, pessoal, autônoma?". E ainda, no desterro do seu próprio ser, se questiona o narrador: "Será este nosso desengonço e mundo o plano - intersecção de planos - onde se completam de fazer as almas?" (ROSA, 1994, p. 441 e 442).

No espelho machadiano, o narrador afirma que "cada criatura humana traz duas almas consigo: uma que olha de dentro para fora, outra que olha de fora para dentro..." (Op. cit., p. 346). Como vimos, Machado de Assis fixa o olhar crítico na "alma exterior", aquela "que olha de fora para dentro", num complexo movimento psicológico de incorporação ou interiorização de valores (fatos, objetos, pessoas, opiniões, crenças etc.), denotando alienação do ser, ou mesmo um certo grau de esquizofrenia. Por seu turno, Guimarães Rosa retoma o problema identitário ante a simples, mas misteriosa superfície de um espelho, seguindo em sentido contrário ao do seu antecessor, ou seja, buscando captar a "alma interior", a que se organiza "de dentro para fora". No início de sua reflexão, o narrador (que se diz "positivo, um racional") questiona seu interlocutor com uma pergunta retórica: "Como é que o senhor, eu, os restantes próximos, somos, no visível?” (ROSA, 1994, p. 437). Contudo, tal visibilidade não tem por foco a mera aparência exterior, antes busca as forças, as formas, os seres mais íntimos que habitam em nós: "Os olhos, por enquanto, são a porta do engano; duvide deles, dos seus, não de mim", diz o narrador rosiano, observando ainda que "a espécie humana peleja para impor ao latejante mundo um pouco de rotina e lógica, mas algo ou alguém de tudo faz frincha para rir-se da gente... $\mathrm{E}$ então?" (Idem, p. 438). Rosa dá um salto para o outro lado do espelho, para um lugar de indeterminação das identidades, que é ao mesmo tempo, o lugar dos possíveis, dos devires: "Olhos contra os olhos. Soube-o: os olhos da gente não tem fim." (Idem, p. 439)

Podemos dizer, contudo, que mesmo perseguindo a alma ou a identidade em direções opostas (de fora para dentro e de dentro para fora), Machado de Assis e Guimarães Rosa, na lógica d'“O espelho", deparam-se com 
a falibilidade da percepção e a inevitabilidade dos processos equívocos da consciência humana ante os fundamentos do ser e os mistérios profundos das aparências.

\section{Considerações Finais}

Como diz o filósofo Gilles Deleuze, “o estilo, num grande escritor, é um estilo de vida, não é de maneira nenhuma qualquer coisa de pessoal, é a invenção de uma possibilidade de vida, de um modo de existência" (1996, p. 80). Os dois escritores que, em 1908, de alguma forma, se cruzam pela primeira vez, têm o dom do estilo na acepção plena da palavra - um perceber e um proceder inconfundíveis, força ativa que alimenta a língua e desperta a alma, ou as almas de um povo.

$\mathrm{Na}$ escrita de Machado de Assis, sobressai uma performance textual que enreda o leitor (desafiando-o) nos jogos de disseminação de discursos, de dissimulação de propósitos, de manipulação de valores. Tais processos presentificam, no corpo da clássica escrita machadiana, um campo de forças próprio do contexto social e humano abordado pelo escritor. Trata-se da sofisticação metacrítica e paródica dos discursos, marcada pelos sinais reversíveis e paradoxais do humor e da ironia, a serviço de uma visão demolidora do status quo e de uma reordenação das forças psicológicas, políticas e sócio-culturais que atuam na base da vida social brasileira. Com Machado, ganha forma e densidade um novo e crítico panorama da realidade nacional, em suas múltiplas determinações. Sobressai a esgrima da língua na desconstrução do real aparente, subvertendo princípios e instigando a reflexão cética.

$\mathrm{Na}$ escrita de Guimarães Rosa, manifesta-se uma performance textual que desafia o leitor (enredando-o) nos jogos de disseminação de códigos, de incorporação da alteridade, de radicalização das forças formais encenadas no texto. Trata-se da emergência de novos códigos literários e, com eles, de imprevistas facetas da condição humana, do universo sertanejo e do inventário lingüístico nacional. Com Rosa, florescem novas potencialidades da língua brasileira, cuja plasticidade modula uma infinidade de afectos e perceptos do "homem humano". Sobressai a confiança na capacidade instauradora da língua em seu estatuto literário, revertendo dados empíricos e emulando o real. 


\section{Referências Bibliografia}

ASSIS, Machado de. Obra completa. Rio de Janeiro: Nova Aguillar, 3 v., 1994.

BARTHES, Roland. Aula. São Paulo: Cultrix, s/d.

BORGES, Jorge Luis. História universal da infâmia. Porto Alegre: Globo, 1986.

BOSI, Alfredo (Org.). Machado de Assis: Antologia e Estudos. São Paulo: Ática, 1982.

CALLADO, Antonio. Introdução. In: Ernst Fischer. A necessidade da arte. Rio de Janeiro: Zahar, 1983, p. 7 a 10.

CALlADO, Antonio. Mesa-Redonda. In: Alfredo Bosi (Org.). Machado de Assis: Antologia e Estudos. São Paulo: Ática, 1982, p. 310 a 343.

CANDIDO, Antonio. Sagarana. In: Eduardo F. Coutinho (org.). Guimarães Rosa: Fortuna Crítica. Rio de Janeiro: Ed. Civilização Brasileira, 1991, p. 243 a 255.

DELEUZE, Gilles. O mistério de Ariana. Lisboa, Portugal: Veja Passagens, 1996.

DELEUZE, Gilles. Conversações. Rio de Janeiro: Ed. 34, 1992.

DELEUZE, Gilles. Lógica do sentido. São Paulo: Perspectiva, 1974.

FISCHER, Ernst. A necessidade da arte. Rio de Janeiro: Zahar, 1983.

ISER, Wolfgang. Os atos de fingir ou O que é fictício no texto ficcional. In: Luiz Costa Lima (org.). Teoria da literatura em suas fontes. Rio de Janeiro: Francisco Alves, 1983, p. 384 a 416.

MONEGAL, Emir Rodríguez. Em busca de Guimarães Rosa. In: João Guimarães Rosa. Fortuna crítica. Rio de Janeiro: Civilização Brasileira, p. 4761, 1991.

PAZ, Octavio. O arco e a lira. Rio de Janeiro: Nova Fronteira, 1982.

PEREIRA, Rubens E. Alves. Segundas estórias e outros enigmas. In: Lélia Parreira Duarte, Outras margens: estudos da obra de Guimarães Rosa. Belo Horizonte: Autêntica/Ed. PUC-Minas, p. 251-265, 2001. 
PEREIRA, Rubens E. Alves. Fraturas do texto: Machado e seus leitores. Rio de Janeiro: Sette Letras, 1999.

ROSA, João Guimarães. Ficção completa. Rio de Janeiro: Nova Aguillar, v. I e II, 1994.

ROSA, João Guimarães. Grande sertão: Veredas. Rio de Janeiro: José Olympio, 1967.

SANTAELLA, Lucia. A assinatura das coisas: Peirce e a literatura. Rio de Janeiro: Imago, 1992.

SANTOS, Boaventura de Sousa. Pela mão de Alice: o social e o político na pós- modernidade. São Paulo: Cortez, 1996.

VERÍSSIMO, Luis Fernando. Ironic mode. Salvador: Jornal A Tarde, 14/10/2007, p. 26.

WHITE, Hayden.. Apud Luis Fernando Veríssimo. In Ironic mode. Salvador: Jornal A Tarde, 14/10/2007, p. 26.

Recebido em 25 de novembro de 2007

Aceito em 25 de fevereiro de 2008 